УДК $378.147: 004.032 .6: 7$

Гаврілова Людмила Гаврилівна

кандидат мистецтвознавства, доцент, докторант

Інститут інформатики НПУ імені М. Драгоманова, м. Київ, Україна

lusjamuz@mail.ru

\title{
ВИКОРИСТАННЯ ОСВІТНЬОГО ВЕБ-САЙТУ «МУЛЬТИМЕДІЙНІ ТЕХНОЛОГІЇ В МУЗИЧНІЙ ОСВІТІ» У ФОРМУВАННІ ПРОФЕСІЙНОӤ КОМПЕТЕНТНОСТІ МАЙБУТНІХ УЧИТЕЛІВ МУЗИКИ
}

\begin{abstract}
Анотація. Стаття присвячена актуальній проблемі сучасної вищої освіти - оновленню засобів навчання i створенню єдиного інформаційного освітнього простору. Авторка визначає поняття «освітні веб-ресурси», «освітній веб-сайт», подає диференціацію сайтів за ї використанням у різних сферах освіти. Висвітлена структура і змістове наповнення персонального сайту «Мультимедійні технології в музичній освіті», який використовується як освітній. Проаналізовані методичні підходи до його застосування у процесі вивчення музично-історичних дисциплін у педагогічному виші («Історія музичного мистецтва», «Історія української музики» тощо); наведені деякі методичні прийоми щодо застосування навчально-методичних матеріалів сайту в процесі формування професійної компетентності майбутніх учителів музики; запропоновані приклади завдань для самостійної роботи студентів, які були апробовані у процесі викладання названих навчальних курсів.
\end{abstract}

Ключові слова: освітній веб-сайт; мультимедійні навчальні засоби; професійна компетентність; майбутні учителі музики.

\section{1. ВСТУП}

Постановка проблеми. Однією 3 провідних тенденцій сучасної освіти $\epsilon$ оновлення засобів навчання. Поняття «засоби навчання», яке існувало в традиційній моделі освіти, наразі поступово трансформується в категорію «єдиного інформаційного освітнього простору», що реалізується в процесі розвитку інформаційнокомунікаційних технологій як система www-серверів та інших Інтернет-ресурсів i процесів. До науково-педагогічного обігу входять поняття «освітній веб-ресурс», «освітній веб-сайт» тощо.

Використання електронних освітніх ресурсів стає перспективним напрямком оновлення системи формування професійної компетентності майбутніх учителів, їх теоретичної і практичної готовності до здійснення педагогічної діяльності. Майбутні вчителі музики також залучаються до інформаційного освітнього простору, усе більшого значення у їхній професійній підготовці набувають музично-комп'ютерні технології. До структури професійної компетентності вчителя музики міцно увійшла інформаційна компетенція (У розумінні дефініцій “компетенція" і “компетентність” ми виходимо 3 визначень вітчизняних дослідників (Н. Бібік, О. Овчарук, О. Савченко та ін. [1; 2]): компетенція об’єктивна категорія, суспільно визнаний рівень знань, умінь, навичок, ставлень тощо у певній сфері діяльності людини як абстрактного носія; компетентність - інтегрована характеристика якості особистості, сформована через знання, уміння і навички, ставлення, поведінкові реакції і здатність самостійно розв'язувати завдання в конкретній діяльнісній сфері.), яку визначають як уміння шукати, добирати інформацію і працювати 3 нею, як вільне володіння сучасними інформаційними і мультимедійними технологіями.

Аналіз досліджень і публікацій. Освітні веб-ресурси (ОВР), за визначенням Г. Стеценка [3], - це інформаційні дані, що можуть бути представлені у вигляді текстових, графічних, звукових, відеоформатах або їх комбінацій, які відображають певну предметну галузь освіти і призначені для забезпечення процесу навчання 
особистості, формування іiі знань, умінь та навичок. Освітні веб-ресурси - це фактично електронні освітні ресурси, розміщені у веб-просторі локальної (Інтранет) чи глобальної мережі (Інтернет).

Освітній веб-сайт (OBC) - поняття, вужче за попереднє. Воно ще не отримало однозначного визначення, його почасту поєднують 3 більш конкретним поняттям «навчальний веб-сайт» (коли йдеться про групу веб-сторінок, пов'язаних гіперпосиланнями, інформаційне наповнення яких цілком пов'язано 3 конкретною навчальною дисципліною або іншим елементом змісту навчання). До освітніх вебсайтів відносять і веб-сайти шкіл, і веб-сайти навчаючих програм, і сайти, які сприяють впровадженню нових форм організації навчального процесу, і сайти для забезпечення навчально-методичного супроводу освітнього процесу. Досить широке визначення надає I. Государєв, який тлумачить освітній веб-сайт як інформаційний ресурс освітнього призначення, виконаний засобами веб-технологій [4].

Російська дослідниця Т. Яшина, вивчаючи освітній веб-сайт як складову єдиного інформаційного освітнього простору, розуміє його як сукупність веб-сторінок з єдиним дизайном, які забезпечують цілеспрямований процес навчання й виховання, розташовані на одному сервері й можуть використовуватися в атестації учнів [5; 6]. Основними характеристиками ОВС Т. Яшина вважає його зміст, дизайн, технічну реалізацію й експлуатаційність.

Диференціація освітніх веб-сайтів зроблена вченими (Л. Жук [7], С. Матвєєва [8], О. Самборська [9]) за їх використанням у різних сферах освіти: сайти для дистанційного й очного навчання певних курсів; сайти для дослідницької діяльності; сайти консультативного призначення; сайти віртуальних методичних об'єднань; сайти інформаційних Інтернет-проектів; сайти навчальних закладів; сайти для розповсюдження культурно-освітньої інформації; сайти освітньо-довідникового характеру (електронні енциклопедії, сайти-словники, бази даних); сайти змішаного типу. Існує також навчальна преса (сайти педагогічних періодичних видань) i персональні сайти науковців, викладачів, інших представників освіти.

Мета статі - висвітлити структуру і змістове наповнення освітнього веб-сайту «Мультимедійні технології в музичній освіті» i методичні підходи до його використання у процесі формування професійної компетентності майбутніх учителів музики, зокрема у вивченні музично-історичних і музично-педагогічних дисциплін у педагогічному виші.

\section{2. МЕТОДИ ДОСЛІДЖЕННЯ}

Під час дослідження використовувались такі методи: аналіз наукових і навчальнометодичних джерел 3 проблем використання освітніх веб-сайтів у процесі впровадження новітніх інформаційних технологій у систему підготовки майбутніх учителів; вивчення й узагальнення передового досвіду організації застосування мультимедійних технологій у практиці мистецької, зокрема музичної, освіти.

\section{3. РЕЗУЛЬТАТИ ДОСЛІДЖЕННЯ}

Студенти, які вчаться на факультеті підготовки вчителів початкових класів ДВНЗ «Донбаський державний педагогічний університет» (спеціалізація «Музика») й отримують кваліфікацію вчителя музичного мистецтва у початковій школі, опановують цілий комплекс мистецьких дисциплін, серед яких «Історія музичного мистецтва», «Історія української музики», «Мультимедійні технології в мистецькій освіті», 
«Інтегроване вивчення навчального предмету “Мистецтво”» тощо. Для забезпечення сучасного рівня викладання названих предметів автором статті створений освітній вебсайт «Мультимедійні технології в мистецькій освіті» (режим доступу: http://multimusic.com.ua/index.php/ua/).

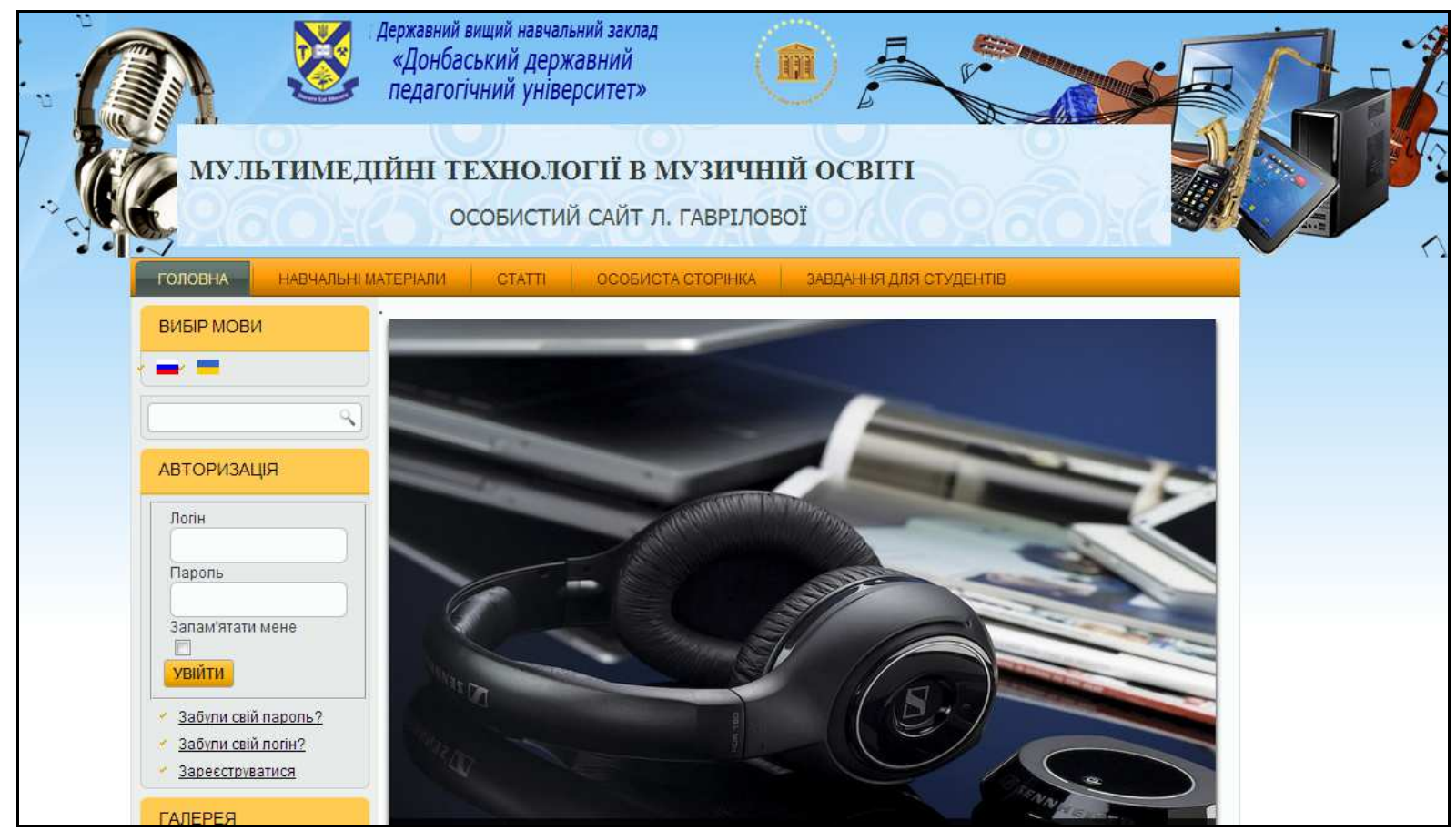

Рис. 1. Головна сторінка освітнього веб-сайту «Мультимедійні технологї у музичній освіті». На верхній панелі - позначення основних структурних компонентів

Перш ніж розглядати структурно-змістове наповнення сайту, зауважимо, що єдині вимоги до структури і контенту освітніх веб-сайтів остаточно ще не відпрацьовані. У дослідженнях окремих науковців (С. Матвєєва [8], Д. Сугак [10], Т. Яшина [5] та ін.) сформульовані деякі вимоги до змісту сайтів (відповідність дидактичним принципам науковості, систематичності, наочності, доступності тощо, структурованість інформації і наявність гіперпосилань, використання засобів мультимедіа, актуальність і сучасність змісту), їх дизайну (естетичні вимоги до кольорового й графічного оздоблення сайту, динамічність), вимоги до технічної реалізації й експлуатаціï освітніх сайтів (функціональність, доступність, високий ступінь інтерактивності, можливість оновлення тощо, урахування потреб реальної категорії користувачів).

Освітній веб-сайт «Мультимедійні технології в мистецькій освіті» створений 3 урахуванням більшості названих вимог. Він використовується як такий тип дистанційного навчання, що частково замінює очне (заочне) навчання (за класифікацією А. Хуторського [11, с. 53], це - окремий тип дистанційного навчання, яке інтегрується у традиційне), коли студенти епізодично звертаються до віддаленого спілкування з педагогом, застосовуючи Інтернет-технології.

\section{1. Структура освітнього веб-сайту}

Сайт «Мультимедійні технології в музичній освіті» структурований у п’ять розділів. 3 головної сторінки відкривається доступ до навчальних матеріалів, які вміщують подані нижче компоненти. 
1. Мультимедійні навчальні матеріали 3 курсу «Історія української музики», який входить до варіативної частини освітньо-професійної програми підготовки спеціаліста початкової освіти, спеціалізація «Музика». Розташовані на сайті мультимедійні матеріали 3 історії української музики складаються 3 навчальної i розгорнутої робочої програм дисципліни; музики для самостійного прослуховування, яка згрупована за темами практичних занять і пропонована для скачування у форматі mp.3; кількох мультимедійних презентацій з різних тем курсу. Для поглибленого вивчення певних розділів історії української музики створений електронний навчальний посібник «Українська духовна музика», посилання на Інтернет-адресу якого також дається на головній сторінці сайту.

2. Матеріали до вивчення професійно зорієнтованого курсу «Історії музичного мистецтва» (розділ «Російська музика»), серед яких мультимедійний підручник «Історія російської музики: від найдавніших часів до початку XX століття» (дається посилання для скачування), програми курсу тощо.

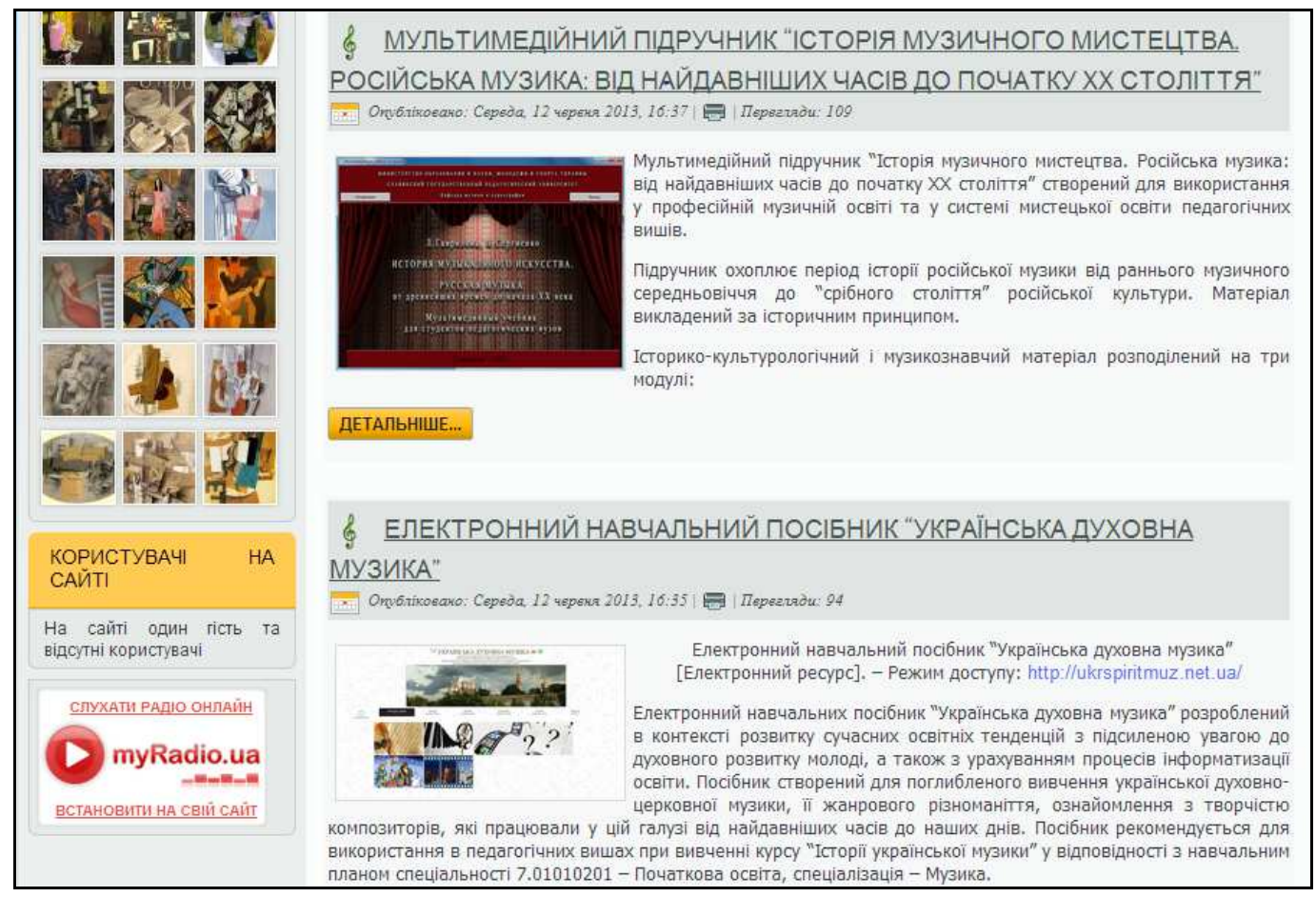

Рис. 2. Мультимедійні навчальні матеріали з музично-історичних дисичиллін на освітньому веб-сайті «Мультимедійні технології в музичній освіті»

3. Електронний навчально-методичний комплекс спецкурсу «Мультимедійні технології в мистецькій освіті», який вивчається студентами факультету підготовки початкових класів ДВНЗ «ДДПУ» як вибіркова навчальна дисципліна, включена до освітньо-професійної програми підготовки бакалавра напряму 6.010102 - Початкова освіта. До ЕНМК «Мультимедійні технології в мистецькій освіті» входять навчальна й робоча програма, плани практичних занять, завдання для самостійної роботи студентів, а також електронна версія навчально-методичного посібника з курсу.

4. Навчально-методичні матеріали (програми, мультимедійні презентації, електронні версії двох навчально-методичних посібників), котрі забезпечують «Інтегроване вивчення навчального предмету “Мистецтво"» - ще один курс, який вивчається студентами усіх спеціалізацій факультету. 
Окремий розділ освітнього сайту «Мультимедійні технології в музичній освіті» cmammi: електронні версії авторських публікацій у наукових виданнях 3 питань використання у мистецькій освіті мультимедійних навчальних засобів, а саме підручників i посібників із названих вище дисциплін («Електронний навчальний посібник "Українська духовна музика": зміст, структура, рекомендації до використання у педагогічному вузі», «Використання мультимедійних навчальних засобів при вивченні музично-історичних дисциплін» та ін.). Ці статті є додатковим методичним матеріалом, що допомагає користуватися мультимедійним підручником 3 «Історії музичного мистецтва» та електронним посібником 3 «Української духовної музики». Вони вміщують методичні поради щодо інсталяції мультимедійних навчальних засобів, їхньої структури, специфіки навігації тощо.

Ще в одному розділі виокремлено «Завдання для студентів». Тут розміщені завдання для on line контролю знань і умінь студентів з музично-історичних дисциплін: тестування та музичні вікторини 3 «Історії музичного мистецтва» та «Історії української музики» (завдання на відгадування музичного фрагменту, подані у відкритій в закритій формах).

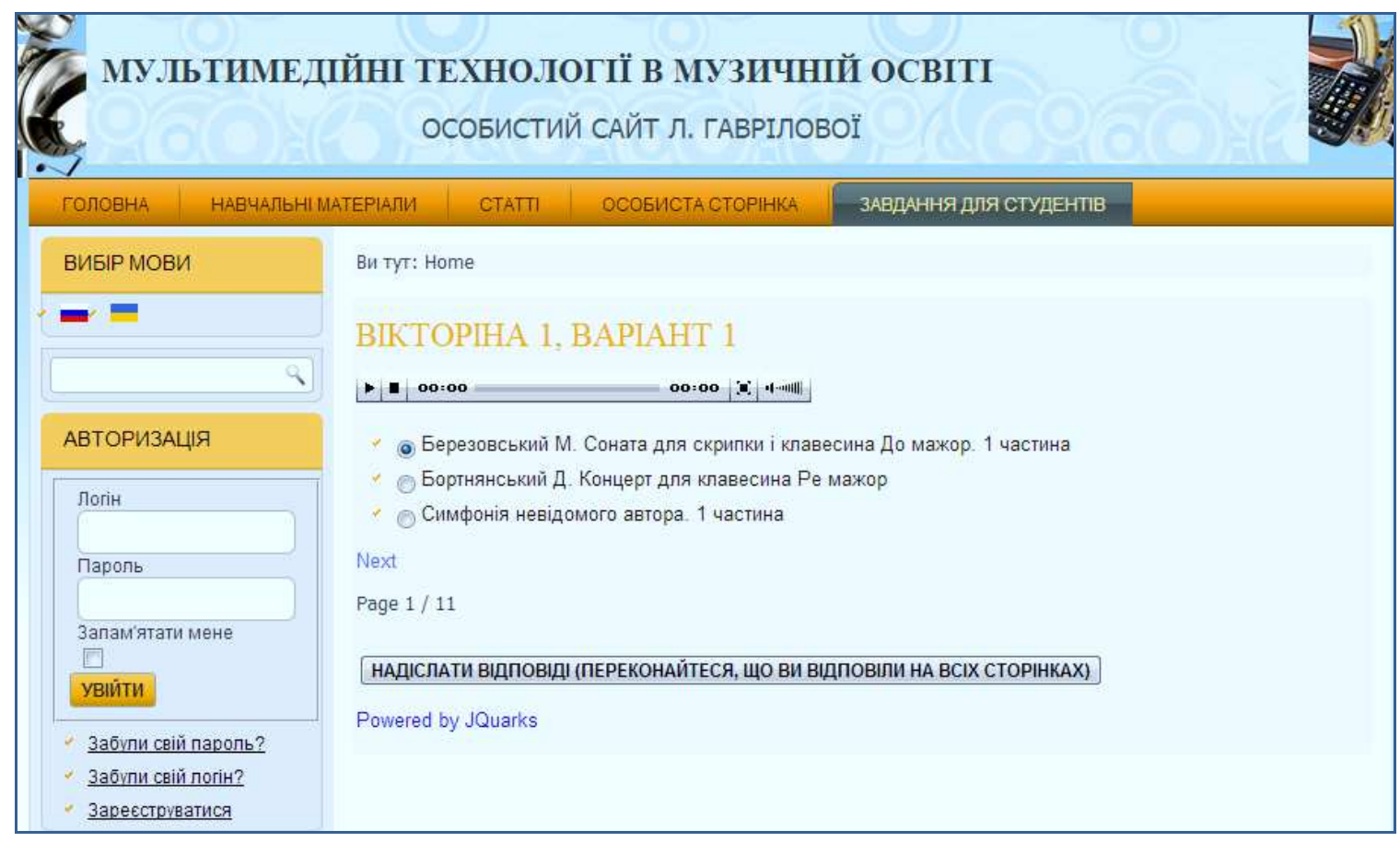

Рис. 3. Розділ сайту «Завдання для студентів»: оп linе вікторина з «Історії української музики»

«Особиста сторінка» знайомить з авторкою сайту, ії науковими здобутками ц надає інформаційні канали зв' язку.

Окрім основних розділів, на боковій панелі кожної сторінки сайту розташовані кнопки вибору мови (сайт створений на українській і російській мовах), пошуку, реєстрації користувачів й авторизації. Відвідувачам сайту пропонується також переглянути арт-галерею (добірка репродукцій творів відомих художників П. Пікассо, Ж. Брака, К. Малевича та ін. майстрів XX століття, які демонструють оригінальний погляд на музичне мистецтво), послухати класичну музику on-line. 


\section{2. Методичні прийоми використання веб-сайту у процесі опанування мистецьких дисциплін}

Веб-сайт «Мультимедійні технології в музичній освіті» використовується у процесі формування професійної компетентності майбутніх учителів музики для забезпечення вивчення окремих мистецьких і музично-історичних дисциплін у кількох напрямках.

1. Для розміщення, систематизації, збереження i використання різного навчального матеріалу, як текстового, так і мультимедійного.

2. Для організації тестового контролю і проведення вікторин (контроль знання музики на слух) з музично-історичних дисциплін on-line.

3. Для забезпечення і спрямування самостійної роботи студентів.

Викладання названих мистецьких дисциплін передбачає комплексне використання матеріалів освітнього веб-сайту як в аудиторній роботі, так і в процесі самостійної навчальної діяльності користувачів.

Наведемо методичні прийоми застосування навчально-методичних матеріалів сайту на лекційних заняттях:

- для звернення уваги студентів на ключові поняття історії музики й ілюстрації теоретичних положень щодо художньо-естетичних напрямків музичного мистецтва пропонуються мультимедійні презентації, які вміщують репродукції, фотозображення, аудіо і відеофрагменти музичних спектаклів;

- для підсилення емоційного впливу й отримання додаткової інформації з окремих тем історії української музики до розповіді лектора додаються слайд-шоу про українські Лаври (Києво-Печерську, Почаївську, Святогірську) з електронного навчального посібника «Українська духовна музика» - п’ятихвилинні ролики вміщують інформацію про історію і сьогодення трьох вітчизняних духовнорелігійних центрів, їхні музичні традиції;

- для досягнення більшої дидактичної ефективності перегляду слайд-шоу i мультимедійних презентацій застосовується методичний прийом активізації уваги: на початку перегляду викладач надає студентам перелік питань, на які слід відповісти, щоб привернути увагу до найважливіших моментів.

Ці методичні прийоми дозволяють організувати навчально-виховний процес на лекціях в активно-дієвій формі.

Використання освітнього веб-сайту надає можливість сформулювати нові форми творчих завдань із самостійної роботи студентів, запропонувати їх та проконтролювати виконання.

Наведемо приклади завдань, апробованих у процесі викладання названих мистецьких дисциплін.

1) Створити аналітичний етюд - надати аналіз-інтерпретацію музичного твору українського (російського) композитора (зі слухання музики у початкових класах): для допомоги пропонуються електронні версії підручників 3 аналізу музичних творів, рекомендується звернення до електронного мультимедійного посібника, нотні й аудіоматеріали. Це завдання вимагає від студентів висловлення власних думок щодо інтерпретації змісту музичних творів, роздуму про засоби музичної виразності, їх композиційно-драматургічну організацію. До того ж аналіз музики має бути спрямований на школярів початкових класів, які слухатимуть їі на уроці, і надихати учнів на власну інтерпретацію музичного змісту.

2) Презентувати одну з українських (російських) опер за власним сценарієм, використовуючи мультимедійні матеріали (аудіо і відеофрагменти, фотоматеріали, репродукції творів образотворчого мистецтва тощо). Презентація може бути створена у програмі MS PowerPoint або розроблена як рекламний буклет у програмі MS Publisher, 
змонтована у вигляді відеоролику формату AVI тощо. У плані змісту це може бути подорож в історію опери, сторінка іiі сучасної долі, презентацію можна вибудувати у вигляді міркувань про оперних героїв або роздумів про іiі жанрово-драматургічні особливості. Тобто відкривається широкий простір для студентської творчості. Питання щодо технічного оформлення цього завдання та усі інші проблеми обговорюються у реальному часі (використовується Skype) або у режимі e-mailлистування.

3) Підготувати творчий портрет композитора у вигляді доповіді 3 мультимедійною презентацією (за вибором): представити власний погляд на життя i творчість митця, проявити пошукові здібності у підготовці мультимедійного наповнення. Для якісного виконання презентації, підготовки мультимедійних фрагментів, обробки відео й аудіо інформації потрібно реалізувати набуту в педагогічному університеті інформаційну компетенцію.

Завдання для самостійної роботи зі спецкурсу «Мультимедійні технології в мистецькій освіті» вимагають активного використання сучасного програмного забезпечення:

1) Підготувати мультимедійні складові (аудіо, відеофрагменти, малюнки, репродукції, відредаговані у програмах Nero Wave Editor, Nero Vision, графічних редакторах тощо) до уроків музики, образотворчого мистецтва, інтегрованого курсу «Мистецтво» у початкових класах».

2) Скласти мультимедійні тести до проміжного чи підсумкового контролю знань на уроці мистецького циклу у початковій школі (програми MS PowerPoint, MyTestX, UniTest System, інші конструктори мультимедійних тестів).

Відзначимо, що наведені завдання належать до творчих форм самостійної роботи студентів, виконання яких залежить від їхнього особистісного досвіду та потребує творчого самовираження.

Окрім того, серед завдань, розроблених для самостійної роботи, присутні й традиційні, тобто такі, що виконуються за визначеним алгоритмом, наданими схемамизразками і використовують традиційні дидактичні прийоми порівняння, узагальнення, аналізу текстового матеріалу:

- скласти план біографії композитора, визначити основні етапи творчого шляху i вказати їх значення для формування художньо-естетичних принципів автора, зазначити найважливіші події у житті композитора;

- скласти систематизований за жанрами список творів композитора 3 короткими поясненнями (літературні або інші програмні першоджерела, автори тексту тощо);

- підготувати хронологічну таблицю з розвитку певного музичного жанру певного історичного періоду (за наведеним зразком).

Виконані самостійно завдання надсилаються викладачеві електронною поштою, найкращі творчі проекти демонструються й обговорюються на практичних заняттях.

Виконання цих завдань включається у загальну систему формування професійної компетентності майбутніх учителів музики, зокрема впливає на розвиток інтелектуальної і культурної компетенцій студентів.

Проміжний і підсумковий контроль теоретичних знань студентів з усіх названих мистецьких дисциплін відбувається у вигляді on-line тестування на сайті, так само перевіряється рівень знання музики на слух (on-line вікторини): протоколи тестування надходять на сторінку адміністратора сайту. Для інтенсифікації контрольнооцінювальної діяльності, а також для того, щоб активізувати увагу студентів виконання тестів і вікторин має обмеження в часі. 


\section{4. ВИСНОВКИ ТА ПЕРСПЕКТИВИ ПОДАЛЬШИХ ДОСЛІДЖЕНЬ}

Використання веб-сайту «Мультимедійні технології в музичній освіті» як електронного освітнього ресурсу у викладанні певних музично-історичних i методичних дисциплін упродовж 2012-2013 і поточного навчального року у Донбаському державному педагогічному університеті дозволило сформулювати такі положення.

1. Викладання історико-теоретичних музичних дисциплін («Історії музичного мистецтва», «Історії української музики»), а також мистецьких курсів методичного спрямування («Мультимедійні технології в мистецькій освіті», «Інтегроване вивчення навчального предмету “Мистецтво”») із застосуванням освітнього веб-сайту, на якому зміст навчального матеріалу подається засобами мультимедіа, а спілкування здійснюється за допомогою телекомунікаційних технологій, сприяє зростанню професійної компетентності майбутніх учителів, у тому числі іiі інформатичної складової.

2. Враховуючи специфіку професійно зорієнтованих історико-теоретичних музикознавчих дисциплін, повноцінне викладання яких потребує обов'язкового спілкування викладача зі студентами, використання освітнього веб-сайту як елементу дистанційного навчання має поєднуватися 3 традиційними очними формами. Проте курси методичної спрямованості («Мультимедійні технології в мистецькій освіті», «Інтегроване вивчення навчального предмету “Мистецтво”») можуть повноцінно засвоюватися і контролюватися в умовах освітнього веб-сайту без особистісного спілкування.

3. За допомогою пропонованих методичних підходів використання освітнього веб-сайту можна розв'язати актуальні дидактичні завдання:

- підвищити рівень сприйняття і розуміння навчальної інформації 3 курсів музично-історичного і мистецько-методичного змісту;

- залучити студентів до активних форм самостійної навчальної діяльності;

- підвищити рівень інтересу з боку студентів до навчального матеріалу з історії музичного мистецтва та інших мистецьких дисциплін.

До того ж робота 3 електронним освітнім ресурсом сприяє формуванню й розвитку інформаційної компетенції майбутніх учителів музики, вдосконалює навички застосування Інтернет-технологій, залучає студентів до активного засвоєння сучасного інформаційно-комунікаційного педагогічного середовища, включається у загальну систему формування професійної компетентності майбутніх педагогів-музикантів. Тому перспективними вважаємо додавання до структури освітнього веб-сайту «Мультимедійні технології в музичній освіті» мультимедійного контенту нових курсів, зокрема навчальних предметів «Аналіз музичних творів» i «Теорія музики i сольфеджіо», удосконалення методичних підходів використання ОВС у вивченні мистецьких дисциплін у педагогічному виші.

\section{СПИСОК ВИКОРИСТАНИХ ДЖЕРЕЛ}

1. Компетентнісний підхід у сучасній освіті: світовий досвід та українські перспективи: Бібліотека 3 освітньої політики / під заг. ред. О. В. Овчарук. - К. : “К.І.С.”, 2004. - 112 с.

2. Савченко О. Я. Компетентнісний підхід як чинник модернізації змісту освіти / О. Я. Савченко // Формування ключових і предметних компетентностей молодших школярів: дидактико-методичні аспекти. Дайджест 2 / укл. О. В. Онопрієнко. - Донецьк : Каштан, 2012. - С. 3-9.

3. Стеценко Г. В. Освітні веб-ресурси та їх класифікація / Г. В. Стеценко // Комп'ютер в школі та сім’ї. - 2007. - №6(62). - С. 23-26. 
4. Государев И. Б. Веб-технологии в школе / И. Б. Государев [Электронный ресурс]. - Режим доступа : http://design.gossoudarev.com).

5. Яшина Т.С. Оценка качества образовательных веб-сайтов как фактор развития единого информационного образовательного пространства : дис. ... канд. пед. наук : 13.00 .01 / Т. С. Яшина. - Воронеж, 2005. - 205 с.

6. Могилев А. В. О понятии и структуре единого информационного образовательного пространства (ЕИОП) / А. В. Могилев, Т. С. Яшина [Электронный ресурс]. - Режим доступа : http://vio.uchim.info/Vio_24/cd_site/articles/art_1_5.htm.

7. Жук Л. Г. Интернет-технологии как средство организации самостоятельной работы студентов технических вузов (на материале обучения иностранному языку) : лис. ... канд. пед. наук : 13.00.03 / Л. Г. Жук. - СПб, 2006. - 192 с.

8. Матвєєва С. А. Сайт як жанр Інтернет-комунікацій (на матеріалі персональних сайтів учених) : дис. ... канд. філол. Наук : 10.02.15 / С. А. Матвєєва. - Луганськ, 2006. - 212 с.

9. Самборська О.Д. Використання тематичних персональних сайтів у навчальному процесі / О. Д. Самборська [Електронний ресурс]. - Режим доступу : http:// barbgpk.at.ua/biblioteka/vikoristannja_tematichnikh_personalnikh_sajtiv_u_n.p.

10. Сугак Д. Б. Веб-сайт кафедры в структуре единой информационной образовательной среды : дис. ...канд. пед. наук :13.00.03 / Д. Б. Сугак. - СПб., 2012. - 327с.

11. Хуторской А. В. Дидактическая эвристика. Теория и технология креативного обучения / А. В. Хуторской. - М. : Изд-во МГУ, 2003. - 416 с.

Матеріал надійшов до редакиії 12.07.2014 p.

\title{
ИСПОЛЬЗОВАНИЕ ОБРАЗОВАТЕЛЬНОГО ВЕБ-САЙТА «МУЛЬТИМЕДИЙНЫЕ ТЕХНОЛОГИИ В МУЗЫКАЛЬНОМ ОБРАЗОВАНИИ» В ФОРМИРОВАНИИ ПРОФЕССИОНАЛЬНОЙ КОМПЕТЕНТНОСТИ БУДУЩИХ УЧИТЕЛЕЙ МУЗЫКИ
}

\section{Гаврилова Людмила Гавриловна}

кандидат искусствоведения, доцент, докторант

Институт информатики НПУ имени М. Драгоманова, г. Киев, Украина

lusjamuz@mail.ru

\begin{abstract}
Аннотация. Статья посвящена актуальной проблеме современного высшего образования обновлению средств обучения и созданию единого информационного образовательного пространства. Автор дает определение понятий «образовательные веб-ресурсы», «образовательный сайт», дифференцирует сайты по их использованию в разных сферах образования. Освещена структура и содержание персонального сайта «Мультимедийные технологии в музыкальном образовании», который используется автором как образовательный. Предлагаются методические подходы к применению веб-сайта в процессе изучения музыкально-исторических дисциплин в педагогическом вузе («История музыкального искусства», «История украинской музыки» и пр.). Приведены некоторые методические приемы использования учебно-методических материалов сайта в процессе формирования профессиональной компетентности будущих учителей музыки; предложены примеры заданий для самостоятельной работы студентов, апробированных в процессе преподавания названных учебных курсов.
\end{abstract}

Ключевые слова: образовательный веб-сайт; мультимедийные учебные средства; профессиональная компетентность; будущие учителя музыки.

\section{USING THE EDUCATIONAL WEB SITE «MULTIMEDIA TECHNOLOGIES IN MUSIC EDUCATION» IN FORMATION OF PROFESSIONAL COMPETENCE OF FUTURE MUSIC TEACHERS}

\author{
Liudmyla H. Havrilova
}

Ph.D. in Art History, assistant professor, Doctoral student in Computer Engineering Department 
National Pedagogical Dragomanov University, Kyiv, Ukraine lusjamuz@mail.ru

\begin{abstract}
The article is devoted to the actual problems of the modern higher education. They are updating of the training aids and the creation of a single informational educational space. The author defines the notions of «educational web resources», «educational site». She also differentiates sites for their use in the various fields of education. There also have been analyzed the structure and the content of the personal website «Multimedia technology in music education», which the author uses as educational. Methodical approaches to the use of the website in the course of studying music-historical disciplines in pedagogical high school have been analyzed too («History of Musical Art», «History of Ukrainian music», etc.). There has been given the examples of the some methodological techniques about the using of teaching materials of the site in the process of the formation the professional competence of future teachers of music. The offered examples of tasks for student's independent work have been tested in the process of teaching these courses.
\end{abstract}

Keywords: educational website; multimedia training tools; professional competence; future music teacher.

\title{
REFERENCES (TRANSLATED AND TRANSLITERATED)
}

1. Competence Approach in Modern Education: International Experience and Prospects of Ukrainian: Library Educational Policy / edited by O. V. Ovcharuk. - K. : K.I.S., 2004. - 112 p. (in Ukrainian).

2. Savchenko O. Ya. Competence Approach as a Factor in the Modernization of Educational Content // Formation of Core and Subject Competencies of Junior Schoolchildren: Didactic and Methodological Aspects. Digest 2 / edited by O. V. Onopriienko. - Donetsk : Kashtan, 2012. - P. 3-9 (in Ukrainian).

3. Stetsenko G. V. Educational Web-Resources and Their Classification // Computer in School and Family. - 2007. - № 6 (62). - P. 23-26 (in Ukrainian).

4. Gosudariev I. B. Web-Technologies at School [Online]. - Available from: http://design.gossoudarev.com (in Russian).

5. Yashina T. S. Quality Evaluation of Educational Websites as a Factor of development of Integral Informational Learning Environment : dis. kand. ped. sciences : 13.00.01. - Voronezh, 2005. - 205 p. (in Russian).

6. Mogilev A. V., Yashina T.S. On the Notion and Structure of Integral Informational Learning Environment [Online]. - Available from: http://vio.uchim.info/Vio_24/cd_site/articles/art_1_5.htm (in Russian).

7. Zhuk L. G. Internet Technologies as Organizing Tools of Students' Individual Work at a Technical University (in Foreign Language Teaching) : dis. kand. ped. sciences : 13.00.03. - Saint Petersburg, 2006. - 192 p. (in Russian).

8. Matveieva S. A. Website as Genre of Internet Communication (on the basis of scientists ' personal sites) : dis. kand. phil. sciences : 10.02.15. - Lugansk, 2006. - 212 p. (in Russian).

9. Samborska O. D. Using Topical Personal Sites in Teaching Process [online]. - Available from: http:// bar-bgpk.at.ua/biblioteka/vikoristannja_tematichnikh_personalnikh_sajtiv_u_n.p. (in Ukrainian)

10. Sugak D. B. The Website of a University Faculty within the Structure of Integral Informational Learning Environment : dis. kand. ped. sciences : 13.00.03. - Saint Petersburg, 2012. - 327 p. (in Russian).

11. Khutorskoi A. V. Didactic Heuristics. Theory and Technology of Creative Teaching. - Moscow : Moscow University Press, 2003. - 416 p. (in Russian). 